\title{
Climate Change Trend Observations in Morocco: Case Study of Beni Mellal-Khenifra and Darâa-Tafilalt Regions
}

\author{
Ait Ouhamchich Kamal1 ${ }^{*}$, Karaoui Ismail ${ }^{1}$, Arioua Abdelkrim1 ${ }^{1}$, Kasmi Atika ${ }^{2}$, Elhamdouni Driss ${ }^{1}$, \\ Elfiraoui Fatima Ezzahra1', Arioua Zakaria1, Nazi Fatima ${ }^{1}$, Nabih Nadia1 \\ ${ }^{1}$ Earth Sciences Department, Faculty of Sciences and Technologies, Béni Mella, Morocco \\ ${ }^{2}$ Regional Meteorology Office, Béni Mellal, Morocco \\ Email: *k.aitouhamchich@usms.ma
}

How to cite this paper: Kamal, A.O., Ismail, K., Abdelkrim, A., Atika, K., Driss, E., Ezzahra, E.F., Zakaria, A., Fatima, N. and Nadia, N. (2018) Climate Change Trend Observations in Morocco: Case Study of Beni Mellal-Khenifra and Darâa-Tafilalt Regions. Journal of Geoscience and Environment Protection, 6, 34-50. https://doi.org/10.4236/gep.2018.67003

Received: March 22, 2018

Accepted: July 8, 2018

Published: July 11, 2018

Copyright $\odot 2018$ by authors and Scientific Research Publishing Inc. This work is licensed under the Creative Commons Attribution International License (CC BY 4.0).

http://creativecommons.org/licenses/by/4.0/

\section{(c) (†) Open Access}

\begin{abstract}
Despite the extreme events impact on various climate events frequency and intensity in many developing countries, there has been dearth information on daily climate trends and climatic extremes. This study comes to characterize the climate type and its evolution in Morocco, specially the two regions Beni Mellal-Khenifra and Darâa-Tafilalt. RClimdex software has been used to calculate pluvio-thermal and ombro-thermic indices in the studied stations to reveal climate type in the two regions, their evolutions, and the daily extreme temperatures and precipitations. A cartographic representation has been done for the calculated indices and climatic trends in the stations from 1970 to 2016. As results, the temperature trend for hot day's number shows a significant increase, while the cold night's numbers, warm sequences, and precipitation are gradually decreases especially at Khouribga and Midelt. These observed modifications influence negatively the annual rainfall total in the year, the consecutive wet days, the maximums rainy days, and the increase of consecutively dry days. As a conclusion, the Martonne aridity and ombro-thermic indices, show that the temperatures and precipitations evolutions do not induce a change in the climate type for the studied regions.
\end{abstract}

\section{Keywords}

Climate Trends, Precipitation, Temperature, RClimdex, Beni Mellal-Khenifra, Darâa-Tafilalt

\section{Introduction}

Climate changes can be defined as the Earth or regional global climate negative 
variations. These changes may be due to intrinsic processes in the Earth, to external influences, or more recently, to human activities [1]. Current climate changes are not considered as an ordinary change due to its magnitude and speed [2].

Since the second Intergovernmental Panel on Climate Change report [3] has highlighted the lack of information on climate trends and variability, and daily climate extremes [4], a number of literature studies of these changes have emerged, both for specific countries [5] [6] [7] [8] [9], then synthesize this information between regions and globally [10] [11] [12]. These studies tended to focus on areas where the daily meteorological observations required for these analyze were already well spaced, controlled and archived [10].

In Africa, numerous regional and national studies on recent trends and variability of the monthly climate synthetize that Africa has undergone in the last 50 years, one of the largest variations in rainfall observed, and noticeable disturbance of different climatic parameters [13] [14] [15] [16] [17].

In Morocco, the quantification of climate change has become a major issue in terms of the dependence of agricultural production and the local economy on water availability. Any change in the frequency or severity of extreme weather and climate events could have a significant impact on nature and society [18].

This research article aims to study the evolution of the observed climate change trends in the two regions Beni Mellal-Khenifra and Darâa-Tafilalet through climatic indices calculated on the basis of observations from the Regional Directorate of Meteorology of Beni Mellal (RDM) and climatological stations.

\section{Materials and Methods}

\subsection{Study Area}

Two administrative regions are attached to RDM, Beni Mellal-Khenifra region that is composed by four large natural groups: the mountain ranges, the piedmont or the Dir, the plateau of the Phosphates of Khouribga, and the Tadla Plain [19]. Darâa-Tafilalt region formed by two large watersheds Darâa and Ziz-Rheris [20] (Figure 1). Administratively, Beni Mellal-Khenifra region is constitute of five provinces (Azilal, Beni Mellal, Fquih Ben Salah, Khenifra and Khouribga), and 135 communes including 16 municipalities and 119 rural communes, while the Darâa-Tafilalt region is formed by five provinces (Errachidia, Midelt, Tinghir, Ouarzazate and Zagora), and 125 municipalities (16 in urban and 109 in rural areas).

\subsection{Data}

The calculated indices in this research article have been done on the basis of daily temperatures observations (maximum and minimum), and precipitations measurement of 5 stations in the study area. These data were measured over a 46-year period (1970 to 2016). The meteorological stations used in this study (Figure 2) location are summarized in Table 1. 


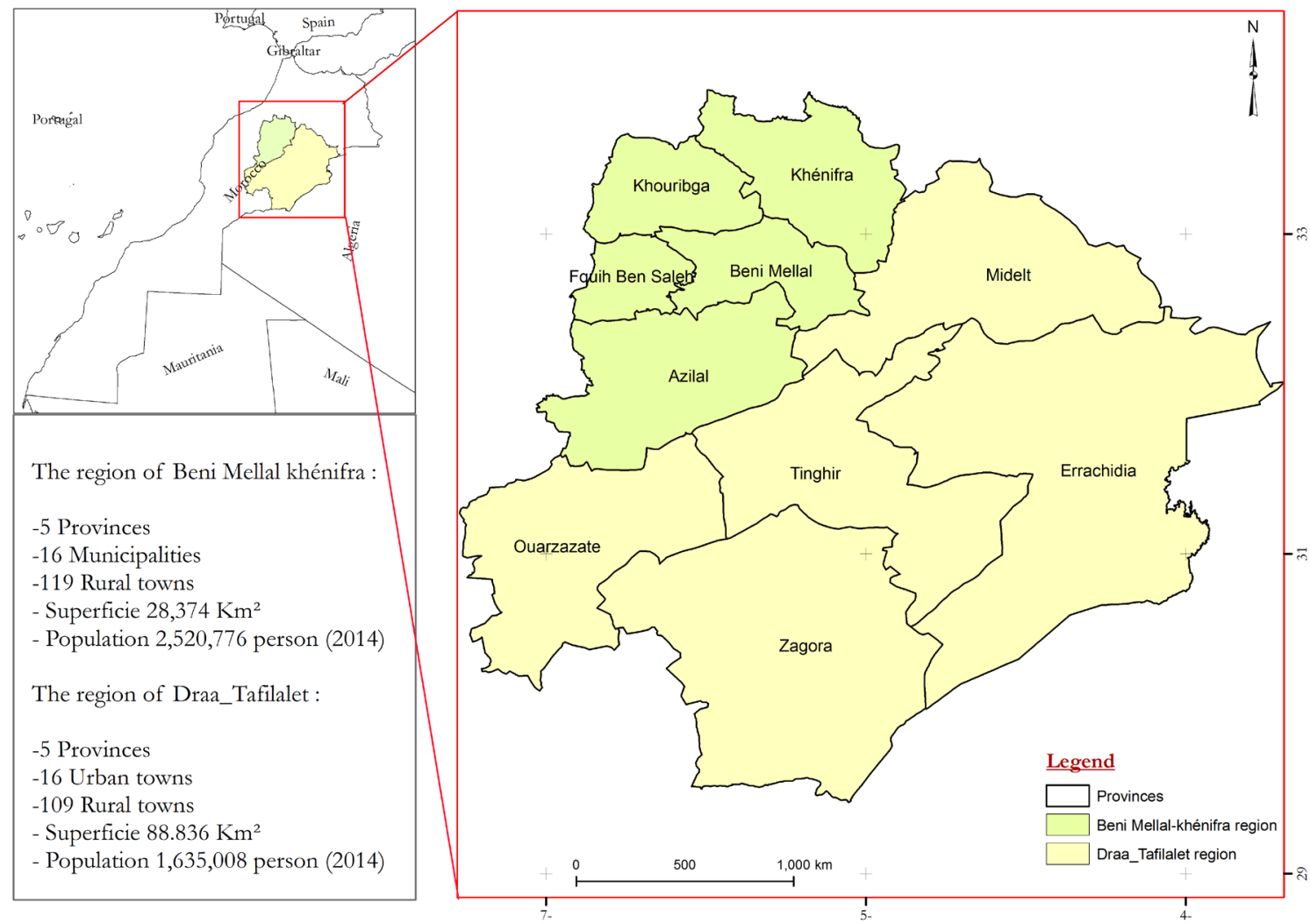

Figure 1. Geographical location of the study area.

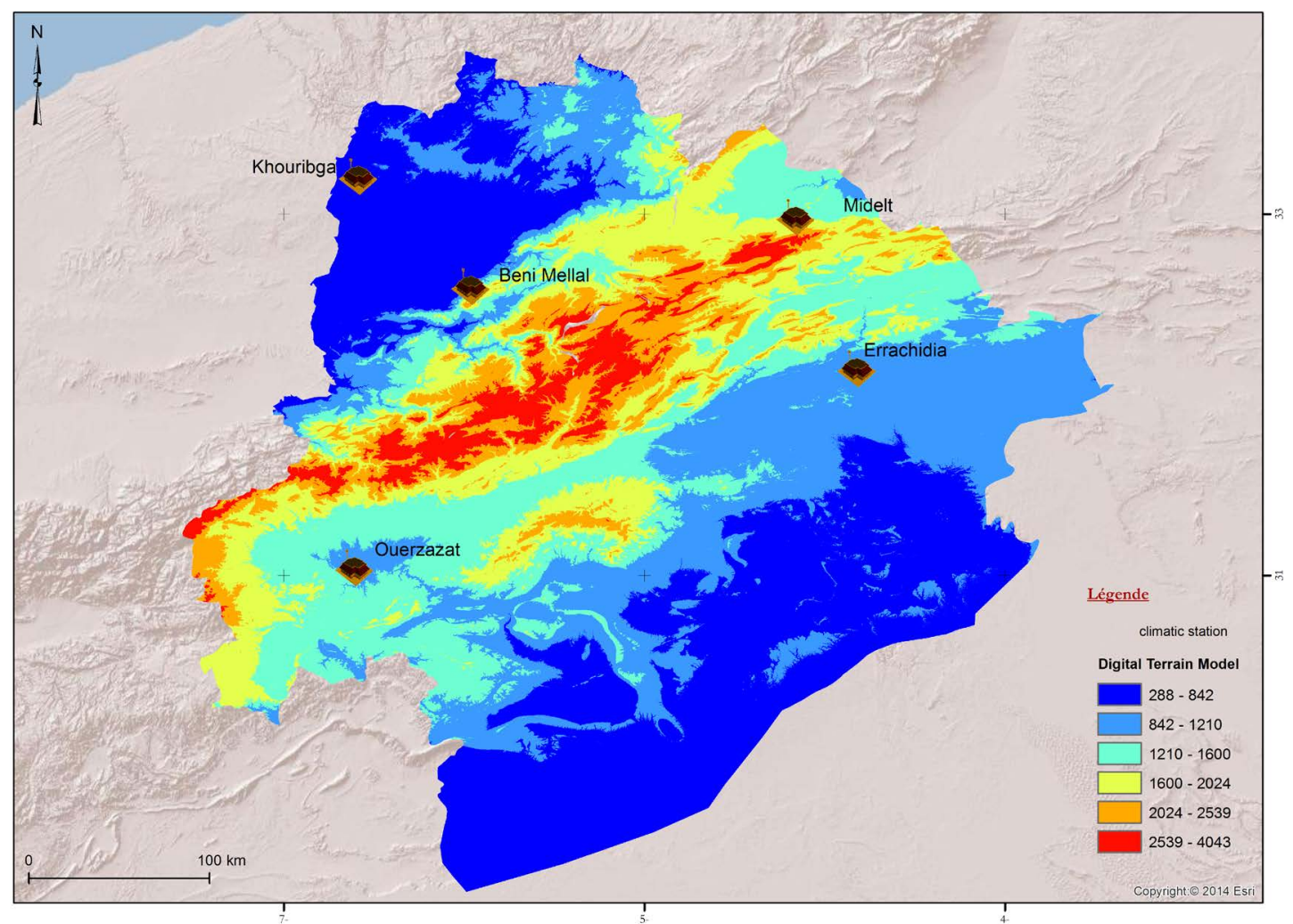

Figure 2. Meteorological stations location on a digital terrain model. 
Table 1. Used stations information.

\begin{tabular}{ccccc}
\hline Information Station & Latitude $\left(^{\circ}\right)$ & Longitude $\left(^{\circ}\right)$ & Altitude $(\mathrm{m})$ & Measurement period \\
\hline Beni Mellal & 32.36 & -6.4 & 472 & $1970-2016$ \\
Midelt & 32.68 & -4.73 & 1508 & $1970-2016$ \\
Ouarzazate & 30.93 & -6.9 & 1136 & $1970-2016$ \\
Khouribga & 32.87 & -6.97 & 785 & $1984-2016$ \\
Errachidia & 31.93 & -4.40 & 1034 & $1973-2016$ \\
\hline
\end{tabular}

Table 2. Martonne aridity index classification.

\begin{tabular}{cc}
\hline Value & Climate \\
$0<\mathrm{I}<5$ & Hyper arid absolute desert \\
$5<\mathrm{I}<10$ & Arid to desert \\
$10<\mathrm{I}<20$ & Semi-arid \\
$20<\mathrm{I}<30$ & Sub wet \\
$30<\mathrm{I}<55(60)$ & wet \\
$\mathrm{I}>55(60)$ & Very wet \\
\hline
\end{tabular}

\subsection{Methods}

In this study we used an open source GIS software for cartography and elaborate all the maps with a World Shaded Relief background projected at WGS 84, and some different indexes has benne calculated for estimate climate trends.

\subsubsection{Martonne Aridity Index}

Aridity index is a number indicating how much more precipitation could be lost by evapotranspirtion if it were available than is actually lost at a givenlocation.

The climate type characterization in Beni Mellal-Khenifra and Darâa-Tafilalt regions has been done using the Martonne aridity index, described as the annual precipitation height $(P)$ and the average annual temperature $(T)$ ratio.

$$
I=P /(T+10)
$$

With:

$P$ : Annual rainfall height (in $\mathrm{mm}$ )

T: Annual temperature average (in ${ }^{\circ} \mathrm{C}$ ) [9]

De Martonne's Index of Aridity has the obvious advantage of showing the transition from one area to another, but it may logically be attacked because of its empirical nature. Nevertheless, it serves as a useful discreet tool in illustrating the slow transition between arid, semiarid, and humid environments.

This index reflects the climatic conditions using the low average annual rainfall and the strong deficit comparison with temperature. The high value of this index due to high rainfall and/or low temperatures led to a wet climate, and the opposite to dry climate as summarized in Table 2. 
In order to characterize the types of climate as well as their evolution, the Martonne aridity index was calculated in the observation period for each meteorological station as well as on two different periods 1970-1990, 1991-2010 and a summary period from 1970-2016.

\subsubsection{Ombro-Thermic Index}

The climate change at the inter-monthly scale characterization has been done using ombro-thermic index, that aims to distinct between dry and wet months that are not easily identifiable, or at least more or less similar.

$$
I_{o}=P-2 T
$$

Wet climate: $I_{o}>0$

Dry climate: $I_{o}<0$

\subsubsection{RClimdex Indices}

The used data quality in this work has been controlled by the Rclimdex software to identify any recording errors that may exist on daily data and influence the characterization results. This processing is based on checking and eliminating values that have anomalies, such as:

- It is not possible to have more than 365 or 366 daily observations per year;

- The month of February must not have more than 28 or 29 observations whatever the year considered;

- The missing data is replaced by -99.9 before controlling the data quality;

- The rain must be between 0 and $200 \mathrm{~mm}$;

- The maximum temperature must be higher than the minimum temperature.

Table 3. Summary information about the used precipitation indices.

\begin{tabular}{|c|c|c|c|}
\hline Identifier & Index name & Definition & Unit \\
\hline RX1day & $\begin{array}{l}\text { Maximum Height of one } \\
\text { day precipitation }\end{array}$ & Maximum total precipitation of a rainy day & $\mathrm{Mm}$ \\
\hline Rx5day & $\begin{array}{l}\text { Maximum cumulative } \\
5 \text {-days precipitation }\end{array}$ & Maximum total precipitation over 5 consecutive rainy days during the year & $\mathrm{Mm}$ \\
\hline SDII & Simple intensity of rainfall & Annual total precipitation over the number of rainy days (PRCP $\geq 1.0 \mathrm{~mm}$ ) & $\mathrm{mm} /$ day \\
\hline R10 & $\begin{array}{l}\text { Number of precipitation days } \geq 10 \\
\qquad \mathrm{~mm}\end{array}$ & Number of days of the year with rainfall $\geq 10 \mathrm{~mm}$ & Day \\
\hline $\mathbf{R} 20$ & $\begin{array}{l}\text { Number of precipitation days } \geq 20 \\
\qquad \mathrm{~mm}\end{array}$ & Number of days of the year with rainfall $\geq 20 \mathrm{~mm}$ & Day \\
\hline Rnn & Number of days above $\mathrm{nn} \mathrm{mm}$ & $\begin{array}{l}\text { the number of days counts in the year whose value is above the threshold set by } \\
\text { the decision maker }\end{array}$ & Day \\
\hline R95p & Very rainy days & Total annual precipitation according to $95^{\text {th }}$ percentile precipitation & $\mathrm{Mm}$ \\
\hline R99p & Extremely rainy days & Total annual precipitation according to $99^{\text {th }}$ percentile precipitation & $\mathrm{Mm}$ \\
\hline PRCPTOT & Annual total rainfall & Total annual precipitation of rainy days $(\mathrm{RR} \geq 1.0 \mathrm{~mm})$ & $\mathrm{Mm}$ \\
\hline CWD & Consecutive rainy days & Maximum number of consecutive days with daily rainfall $\geq 1 \mathrm{~mm}$ & Day \\
\hline CDD & Consecutive dry days & Maximum number of consecutive days with daily rainfall $<1 \mathrm{~mm}$ & Day \\
\hline
\end{tabular}


Table 4. Summary information on the used temperature indices.

\begin{tabular}{cccc}
\hline Identifier & Index name & Definition & Unit \\
\hline TN10p & Relatively cool nights & Percentage of days with $\mathrm{Tmin}<10^{\text {th }}$ Percentile & $\%$ day \\
TX10p & Relatively cool days & Percentage of days with Tmax $<10^{\text {th }}$ percentile & $\%$ day \\
TN90p & Relatively hot nights & Percentage of days with Tmin $>90^{\text {th }}$ percentile & $\%$ day \\
TX90p & Relatively warm days & Percentage of days with Tmax $>90^{\text {th }}$ percentile & $\%$ day \\
WSDI & Hot sequences durations Indicator & Number of days in the year with at least six consecutive days in which Tmax $>$ & $\%$ day \\
& & $90^{\text {th }}$ percentile & $\%$ day \\
CSDI & fresh sequences durations Indicator & Number of days in the year with at least six consecutive days where Tmin $<10^{\text {th }}$ & percentile \\
DTR & Diurnal Thermal Amplitude & Average monthly difference between Tmax and Tmin & ${ }^{\circ} \mathrm{C}$ \\
\hline
\end{tabular}

Based on verified data, the thermal evolution analysis in the Darâa-Tafilalt and Beni-Mellal Khénifra regions has been done using a set of climate indices, calculated annually through RClimdex software for the five stations. These indices allow easy comparison of general climate trends between different regions and climatic zones [21]. A total of 27 indices are proposed to detect climate change in any study area [22] [23] [24] [21]. In our study case, we employed only 18 precipitation and temperature indices shown in Table 3 and Table 4. These indices are considered the most representative in climate change trends.

\section{Results and Discussion}

\subsection{Ombro-Thermic Index}

A semi-arid climate characterized both Beni-Mellal and Khouribga stations. The two stations located near the Middle Atlas benefit from the generated rain that are coming from Atlantic disturbances by reliefs. The hyper-aridity climate in Errachidia and Ouarzazate stations is mainly due to the location downstream of the Atlas, which constitutes a barrier to the oceanic influence of the Atlantic. Midelt is characterized by an arid desert climate caused by geographical position in Middle Atlas downstream, which are preventing the influence of classical disturbances from the Atlantic.

The Martonne aridity index I (equation (3)) results for the 3 periods showed that there are no changes in climate type for 5 studied stations (Table 5).

To characterize the Ombro-thermic index evolution, four periods (1970-1979, 1980-1989, 1990-1999 and 2000-2016) are used as indicator of general climate trend in the study area.

The ombro-thermal index calculation results (Table 6) showed that the wet period is characterized by six months in Khouribga station and seven months for Beni Mellal station on the totality of the studied period (Table 7).

On the other hand, Table 8 and Table 9 showed that the Errachidia and Ouarzazate stations climates during all the year are dry. Concerning, Midelt station climate (Table 10) is characterized by a short wet period (2 to 3 months) and a long dry period (9 to 10 months). 
Table 5. Climate type in studied stations.

\begin{tabular}{cccccc}
\hline Station & Interval & P annuals average & T annuals average & I & Climate type \\
\hline \multirow{3}{*}{ Beni Mellal } & {$[1970-2016]$} & 357.8543 & 19.2121 & 12.2501 & Semi-arid \\
& {$[1970-1991]$} & 410.6570 & 19.0385 & 14.1417 & Semi-arid \\
& {$[1991-2010]$} & 315.5000 & 20.2983 & 10.4130 & Semi-arid \\
Khouribga & {$[1984-2016]$} & 327.4531 & 17.9875 & 11.6999 & Semi-arid \\
& {$[1984-1991]$} & 380.1571 & 19.9800 & 12.6803 & Semi-arid \\
\multirow{3}{*}{ Midelt } & {$[1991-2010]$} & 327.3330 & 18.0211 & 11.6816 & Semi-arid \\
& {$[1970-2016]$} & 186.6304 & 14.8697 & 7.5043 & Arid to desert \\
& {$[1970-1991]$} & 199.9428 & 14.3361 & 8.2158 & Arid to desert \\
& {$[1991-2010]$} & 176.6055 & 16.1327 & 6.7580 & Arid to desert \\
Errachidia & {$[1973-2016]$} & 117.8139 & 20.5632 & 3.8547 & Hyper arid absolute desert \\
& {$[1973-1991]$} & 109.0500 & 19.9777 & 3.6376 & Hyper arid absolute desert \\
& {$[1991-2010]$} & 125.3111 & 22.2294 & 3.8880 & Hyper arid absolute desert \\
& {$[1973-2016]$} & 118.5913 & 19.4223 & 4.0306 & Hyper arid absolute desert \\
\hline \multirow{2}{*}{ Ouarzazate } & {$[1970-1991]$} & 121.7333 & 19.7976 & 4.0853 & Hyper arid absolute desert
\end{tabular}

Table 6. Ombro-thermic index of Khouribga station.

\begin{tabular}{ccccccccccccc}
\hline & Jun & Feb & Mar & Apr & May & June & July & Aug & Sep & Oct & Nov & Dec \\
\hline $\mathbf{1 9 8 4 - 1 9 9 3}$ & 23.3 & 27.9 & 18.9 & 5.2 & -23.2 & -23.2 & -33.3 & -39.7 & -43.2 & -37.1 & -12.7 & 21.1 \\
$\mathbf{1 9 9 4 - 2 0 0 3}$ & 49.9 & 11.5 & 8.4 & 9.4 & -18.6 & -29.1 & -42.1 & -39.8 & -29.3 & -13.8 & 4.1 & 56.1 \\
2004-2016 & 22.1 & 22.1 & 12.1 & -13.1 & -16.2 & -41.5 & -48.3 & -49.2 & -27.2 & -10.6 & 30.6 & 14.5 \\
N=Average(D) & 31.7 & 20.5 & 13.4 & 0.5 & -19.4 & -31.5 & -41.3 & -42.1 & -33.2 & -20.8 & 7.3 & 30.6 \\
\hline
\end{tabular}

Table 7. Ombro-thermic index of Beni Mellal station.

\begin{tabular}{ccccccccccccc}
\hline & Jun & Feb & Mar & Apr & May & June & July & Aug & Sep & Oct & Nov & Dec \\
\hline $\mathbf{1 9 7 0 - 1 9 7 9}$ & 37.1 & 29.7 & 40.8 & 43.3 & -2.9 & -33.4 & -48.0 & -51.4 & -40.8 & 5.2 & 6.8 & 33.3 \\
$\mathbf{1 9 8 0 - 1 9 8 9}$ & 18.7 & 26.7 & 12.5 & 8.6 & -11.7 & -47.3 & -54.3 & -50.0 & -39.8 & -20.8 & 26.4 & 9.4 \\
$\mathbf{1 9 9 0 - 1 9 9 9}$ & 12.7 & 20.8 & 29.7 & 10.5 & -22.2 & -37.7 & -53.3 & -53.3 & -31.3 & -19.8 & 4.1 & 29.1 \\
$\mathbf{2 0 0 0 - 2 0 1 6}$ & 5.2 & 14.6 & 18.0 & -0.3 & -18.1 & -44.1 & -52.3 & -48.9 & -3.5 & 36.8 & 14.1 & 21.3 \\
$\mathbf{N}=$ Average(D) & 18.6 & 23.0 & 25.2 & 15.5 & -13.7 & -40.6 & -51.9 & -50.9 & -28.8 & 0.3 & 12.8 & 23.3 \\
\hline
\end{tabular}

Table 8. Ombro-thermic index of Errachidia station.

\begin{tabular}{ccccccccccccc}
\hline & Jun & Feb & Mar & Apr & May & June & July & Aug & Sep & Oct & Nov & Dec \\
\hline 1973-1982 & 5.1 & -2.8 & -20.0 & -4.1 & -27.1 & -50.6 & -52.4 & -51.1 & -38.2 & -35.1 & -19.8 & -5.7 \\
$\mathbf{1 9 8 3 - 1 9 9 2}$ & -11.8 & -8.9 & -21.9 & -31.4 & -30.3 & -48.3 & -60.7 & -58.8 & -44.8 & -25.8 & -7.5 & -2.6 \\
$\mathbf{1 9 9 3 - 2 0 0 2}$ & -5.3 & -8.2 & -18.3 & -27.3 & -42.4 & -51.4 & -60.7 & -58.1 & -44.6 & -11.5 & -15.6 & -15.5 \\
$\mathbf{2 0 0 3 - 2 0 1 6}$ & -9.9 & -7.7 & -18.5 & -28.4 & -37.2 & -50.5 & -57.4 & -57.5 & -33.5 & -21.6 & -19.8 & -7.3 \\
$\mathbf{N}$ & & & & & & & & & & & &
\end{tabular}


Table 9. Ombro-thermic index of Ouarzazate station.

\begin{tabular}{ccccccccccccc}
\hline & Jun & Feb & Mar & Apr & May & June & July & Aug & Sep & Oct & Nov & Dec \\
\hline $\mathbf{1 9 7 0 - 1 9 7 9}$ & -4.6 & -20.9 & -22.3 & -21.9 & -35.6 & -50.3 & -57.0 & -52.7 & -37.1 & -17.4 & -10.1 & -7.6 \\
$\mathbf{1 9 8 0 - 1 9 8 9}$ & -4.1 & -2.6 & -21.8 & -32.6 & -34.8 & -50.7 & -58.7 & -52.5 & -37.6 & -28.2 & -6.2 & -7.4 \\
$\mathbf{1 9 9 0 - 1 9 9 9}$ & -9.1 & -4.4 & -7.8 & -28.3 & -42.5 & -46.9 & -56.3 & -45.5 & -42.7 & -21.2 & -24.7 & -6.7 \\
$\mathbf{2 0 0 0 - 2 0 1 6}$ & -15.1 & -14.7 & -11.9 & -22.7 & -34.3 & -34.5 & -50.7 & -49.8 & -42.7 & -28.8 & -26.2 & -12.1 \\
$\mathbf{N}$ & -10.2 & -10.5 & -16.0 & -26.4 & -36.8 & -45.6 & -55.7 & -50.1 & -40.2 & -23.9 & -16.8 & -8.5 \\
\hline
\end{tabular}

Table 10. Ombro-thermic index of Midelt station.

\begin{tabular}{ccccccccccccc}
\hline & Jun & Feb & Mar & Apr & May & June & July & Aug & Sep & Oct & Nov & Dec \\
\hline $\mathbf{1 9 7 0 - 1 9 7 9}$ & 8.8 & 11.9 & -1.2 & 19.8 & 1.6 & -6.9 & -33.1 & -40.10 & -27.1 & -10.7 & -6.4 & -7.8 \\
$\mathbf{1 9 8 0}-1989$ & 0.1 & -3.4 & -12.7 & -8.6 & -7.8 & -29.2 & -45.8 & -44.3 & -28.6 & -9.3 & -3.6 & -11.0 \\
$\mathbf{1 9 9 0 - 1 9 9 9}$ & -0.5 & -4.7 & -1.7 & -3.4 & -14.0 & -28.5 & -43.7 & -36.9 & -17.2 & -20.8 & -3.4 & -5.9 \\
$\mathbf{2 0 0 0 - 2 0 1 6}$ & -3.1 & -0.1 & -3.0 & -12.1 & -8.1 & -28.4 & -40.4 & -31.3 & -25.4 & -7.5 & -1.9 & -2.7 \\
$\mathbf{N}=$ Average(D) & 2.8 & 1.2 & -5.2 & 2.5 & -6.7 & -21.5 & -40.9 & -40.4 & -24.3 & -13.6 & -4.4 & -8.2 \\
\hline
\end{tabular}

\subsection{Indices Cartographies}

\subsubsection{General Trend of Temperature Indices}

The observed indices of climate change are calculated from daily precipitation data and temperatures (maximum and minimum) in Khouribga, Beni-Mellal, Midelt, Errachidia and Ouarzazate stations. The data period used are summarized in Table 11.

Table 11. Reference periods used by RClimdex to calculate climate indices.

\begin{tabular}{cccccc}
\hline Station & Errachidia & Ouarzazate & Béni-Mellal & Midelt & Khouribga \\
\hline Reference period & $1973-2000$ & $1970-2000$ & $1970-2000$ & $1970-2000$ & $1984-2000$ \\
\hline
\end{tabular}

We are taking for example the observed trends evolution in Beni Mellal station such as illustrated in Figure 3. The part ((a)-(b)) represent relatively hot days and number of heat wave indices evolution. These two indices have a significant upward trend generally detected on both case. Concerning the rainfall, the part (c) shows a downward trend in the annual cumulative rainfall index, but this trend is not statistically significant.

\section{1) Relatively cool nights (TN10p)}

Figure 4 bellow shows a spatial distribution of TN10p. This index is down significantly and suggests $-0.024 \%$ to $-0.325 \%$ days/year, which leads to a decrease in the number of cold nights. The highest fall value is located in Beni Mellal city ( $-0.325 \%$ of days/year), Errachidia ( $-0.32 \%$ of days/year), Ouarzazate $(-0.295 \%$ of days/year), and Midelt $(-0.274 \%$ of days/year). These trends seem significant in all stations. 


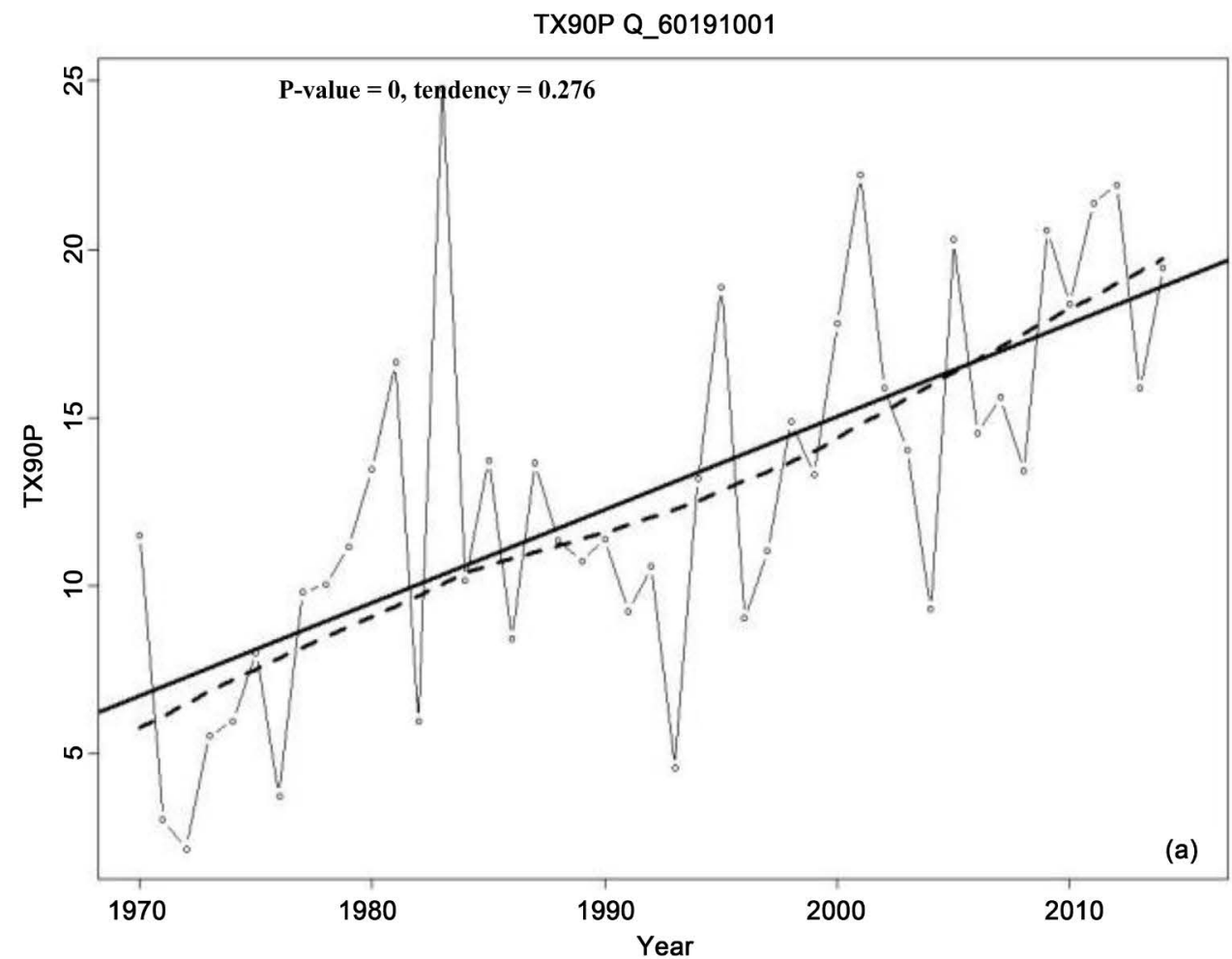

\section{...... Not linear trend \\ L Linear trend \\ $-\circ$ Index evolution}

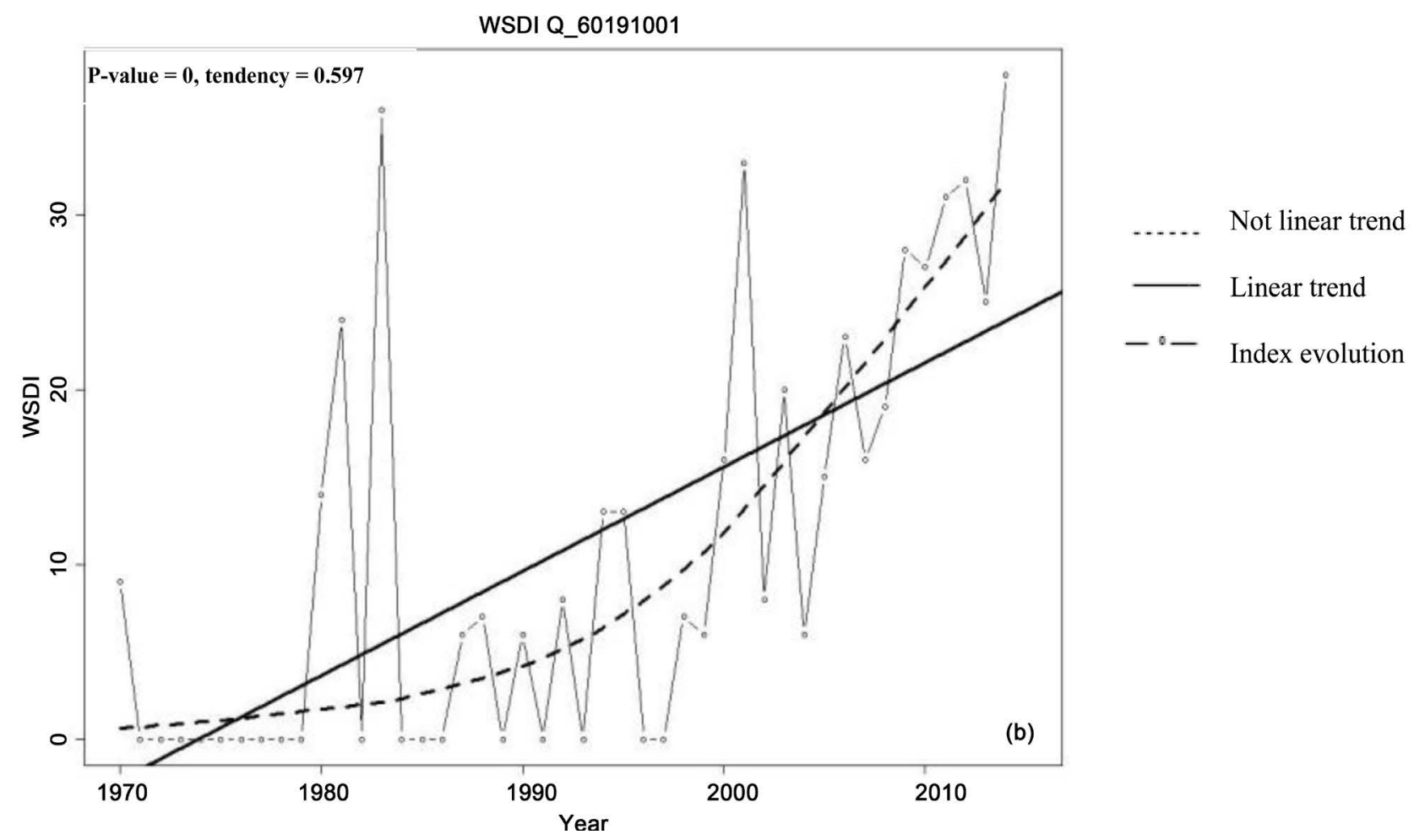




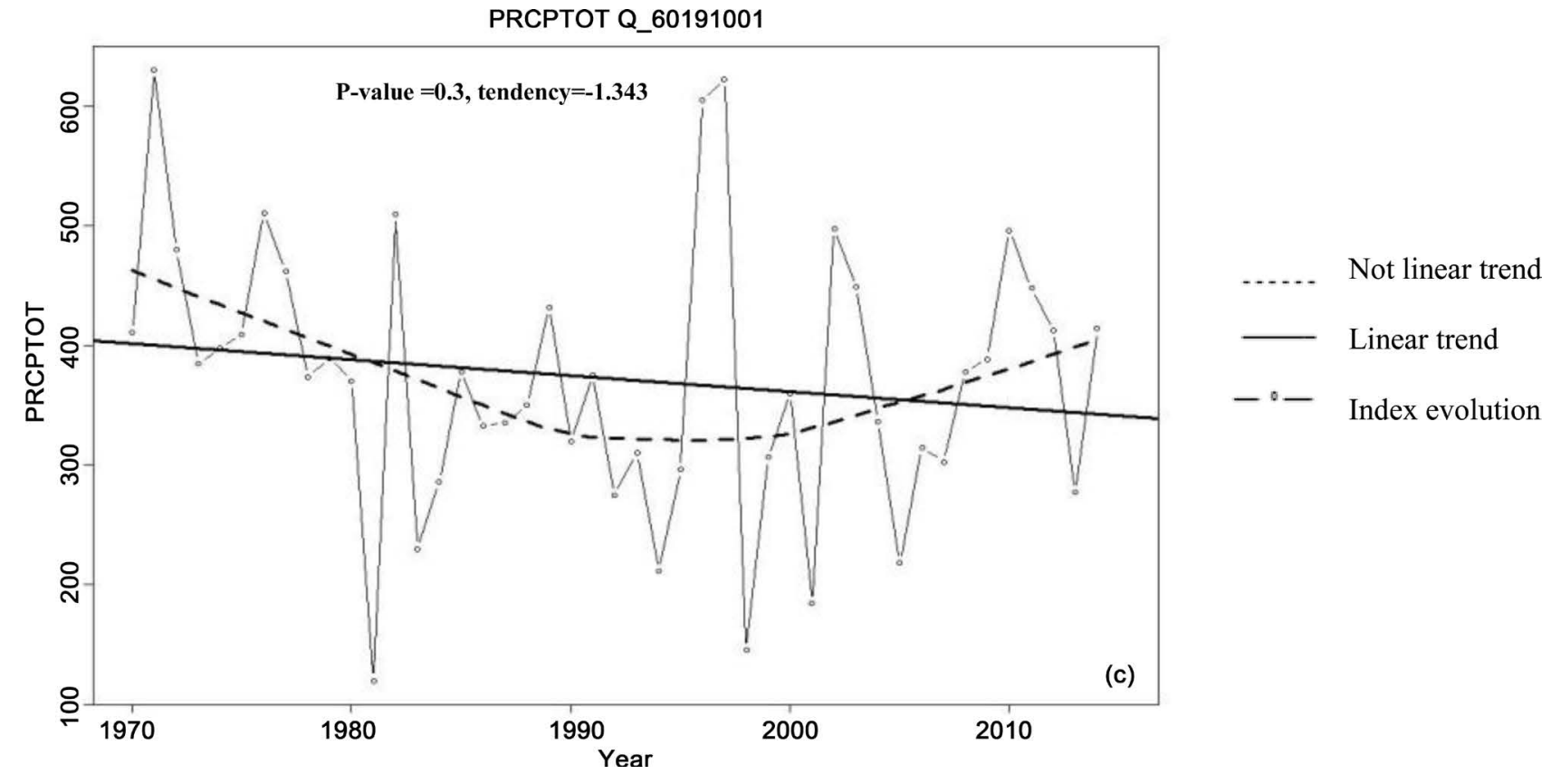

Figure 3. Observed trends evolution in Beni Mellal station for: (a) Relatively hot days index; (b) hot sequences durations index; (c) annual totals of precipitations index.

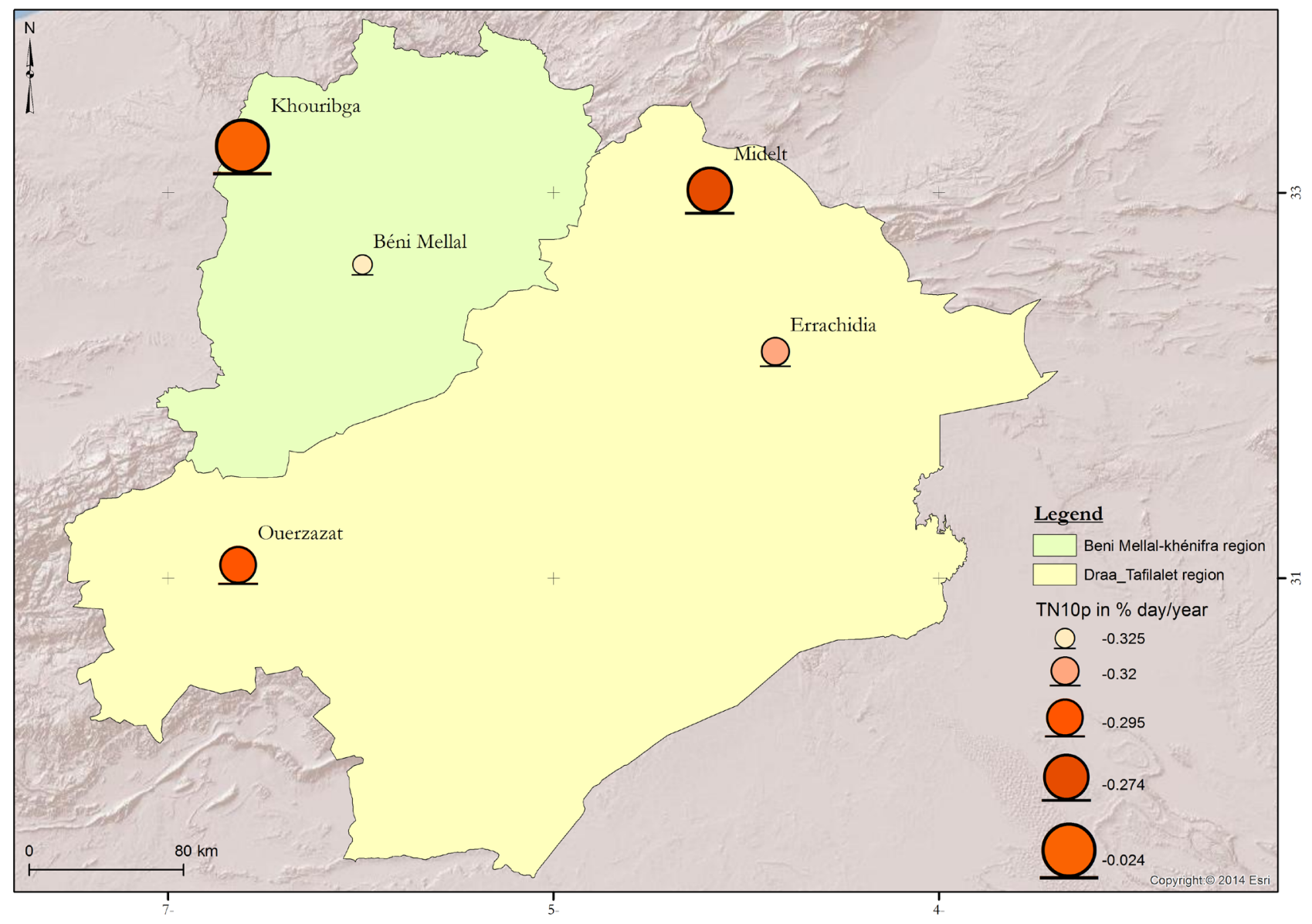

Figure 4. Spatial distribution of the index trends of the fresh nights. 


\section{2) Relatively warm days (TX90p)}

Figure 5 represents the index evolution trend of the relatively warm TX90p days for the five stations of interest. All trends are positive and statistically significant. The hot days shows a real increase. This observation is valid for all the observations analyzed. This increase varies between $0.568 \%$ in days per year $(5 \%$ days per decade) in Errachidia, Ouarzazate (0.489\% of days/year), Khouribga $(0.475 \%$ of days/year), Midelt $(0.397 \%$ of days/year $)$ and $0.276 \%$ days per year equivalent to $2 \%$ day by decade in Beni Mellal.

\section{3) Warm Sequence Duration Indicator (WSDI)/Heat wave}

The WSDI index (Figure 6) express the number of hot days in the year with at least six consecutive days or heat wave. Its results are significant at all stations in the study area. The maximum value is observed at Errachidia with $1.301 \%$ of days/year, followed by Ouarzazate $1.137 \%$ days/year and Khouribga $0.837 \%$ days/year. The minimum value is observed at Midelt with $0.581 \%$ days/year.

Synthesis: The observed global warming in the two regions (Beni Mellal-Khenifra and Darâa-Tafilalt) is characterized by a significant increase in relatively hot days and for the indicator of successive heat duration in Errachidia and Ouarzazate compared to other stations. The cool nights show a decrease on the whole of stations.

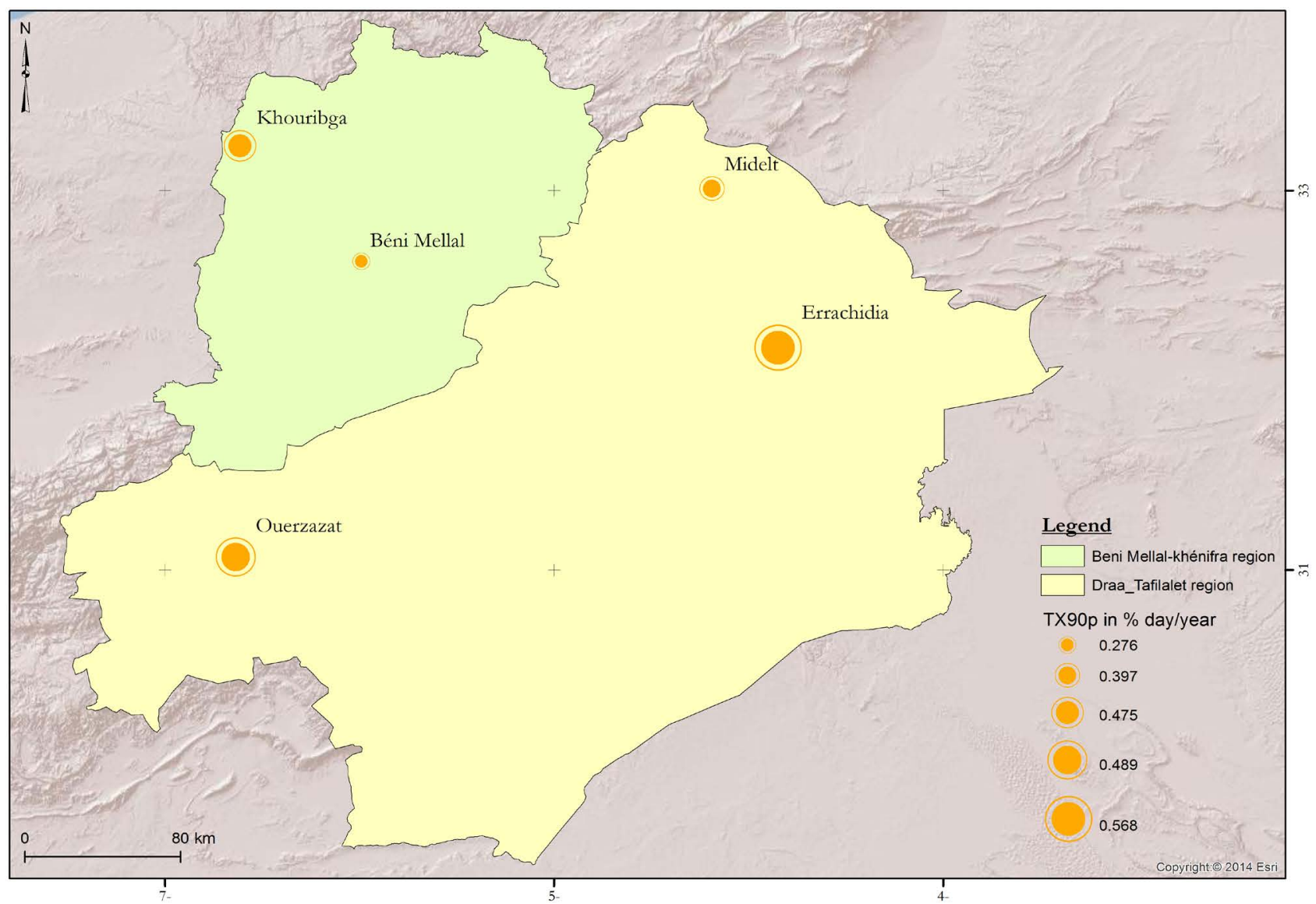

Figure 5. Index evolution trend of the relatively warm. 


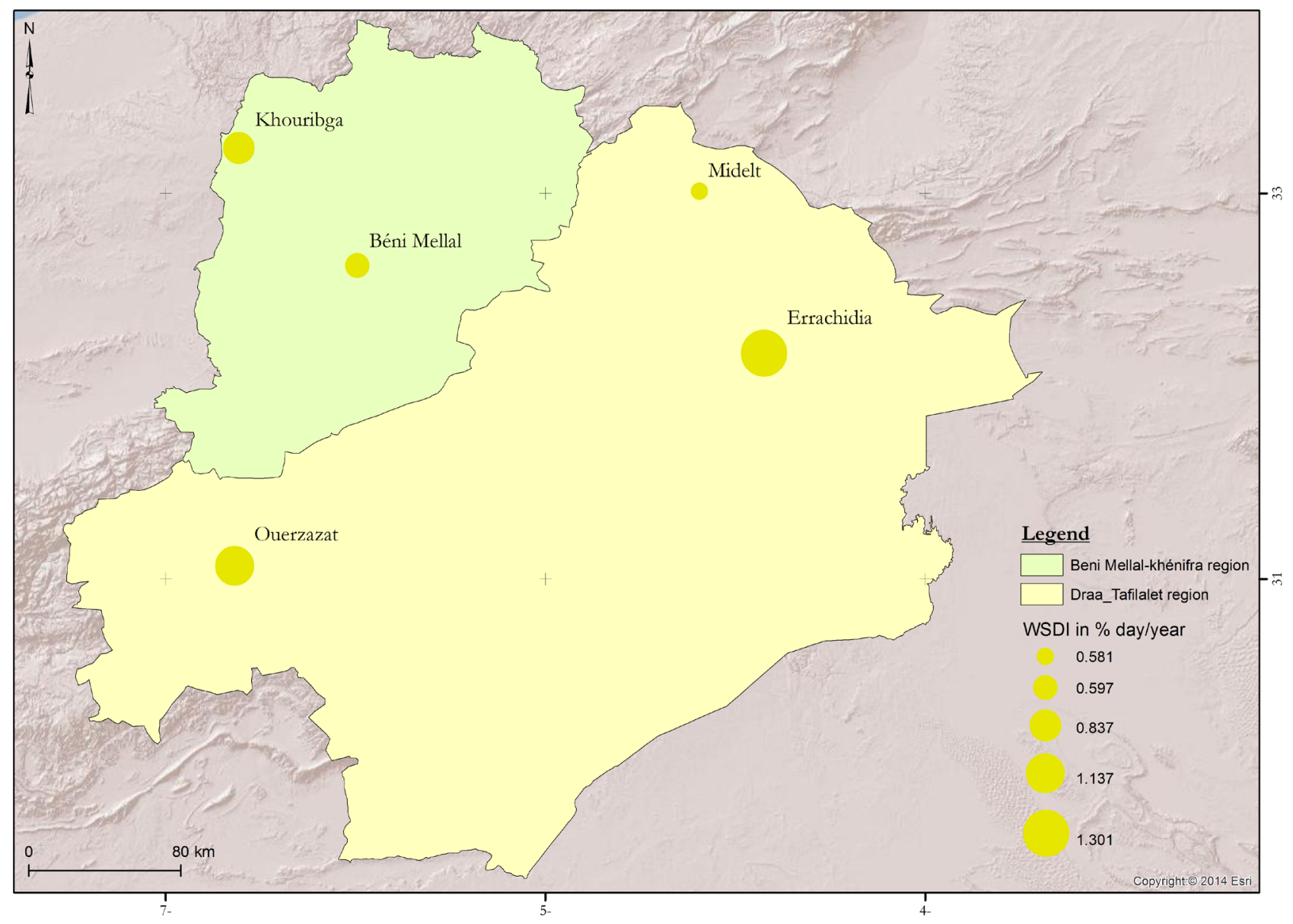

Figure 6. Warm Sequence Duration index variation in the different stations.

\subsubsection{General Trend of Precipitation Indices}

\section{1) Maximum of one rainy day (RX1day)}

The RX1day index map (Figure 7) expresses the maximum height of the precipitation in one day. This trend is more pronounced at Khouribga station where there has been a decrease in the order of $(-0.41 \mathrm{~mm})$ and in Midelt $(-0.005$ $\mathrm{mm})$. On the other hand, Ouarzazate, Errachidia and Beni Mellal show an increase between 0.177 and $0.052 \mathrm{~mm}$.

\section{2) Very wet days (R95p)}

Figure 8 shows that Beni Mellal, Ouarzazate and Errachidia stations have an increasing trend between 0.29 and $0.654 \mathrm{~mm}$. This increase is much accentuated in Beni Mellal with $0.654 \mathrm{~mm}$ and in Ouarzazate $0.429 \mathrm{~mm}$. The downward trend is noticeable especially in Midelt with $-0.627 \mathrm{~mm}$, and Khouribga $-0.299 \mathrm{~mm}$.

\section{3) Annual rainfall totals (PRCPTOT)}

Figure 9 represents the PRCPTOT index that is reflecting the total annual precipitations in rainy days. This totals rainfall index is characterized by a downward trend in the Beni Mellal stations $-1.343 \mathrm{~mm}$, Khouribga $-1.23 \mathrm{~mm}$ and Midelt $-0.417 \mathrm{~mm}$. While in Errachidia and Ouarzazate stations are characterized by an increase in the order of 1.075 and $0.138 \mathrm{~mm}$. 


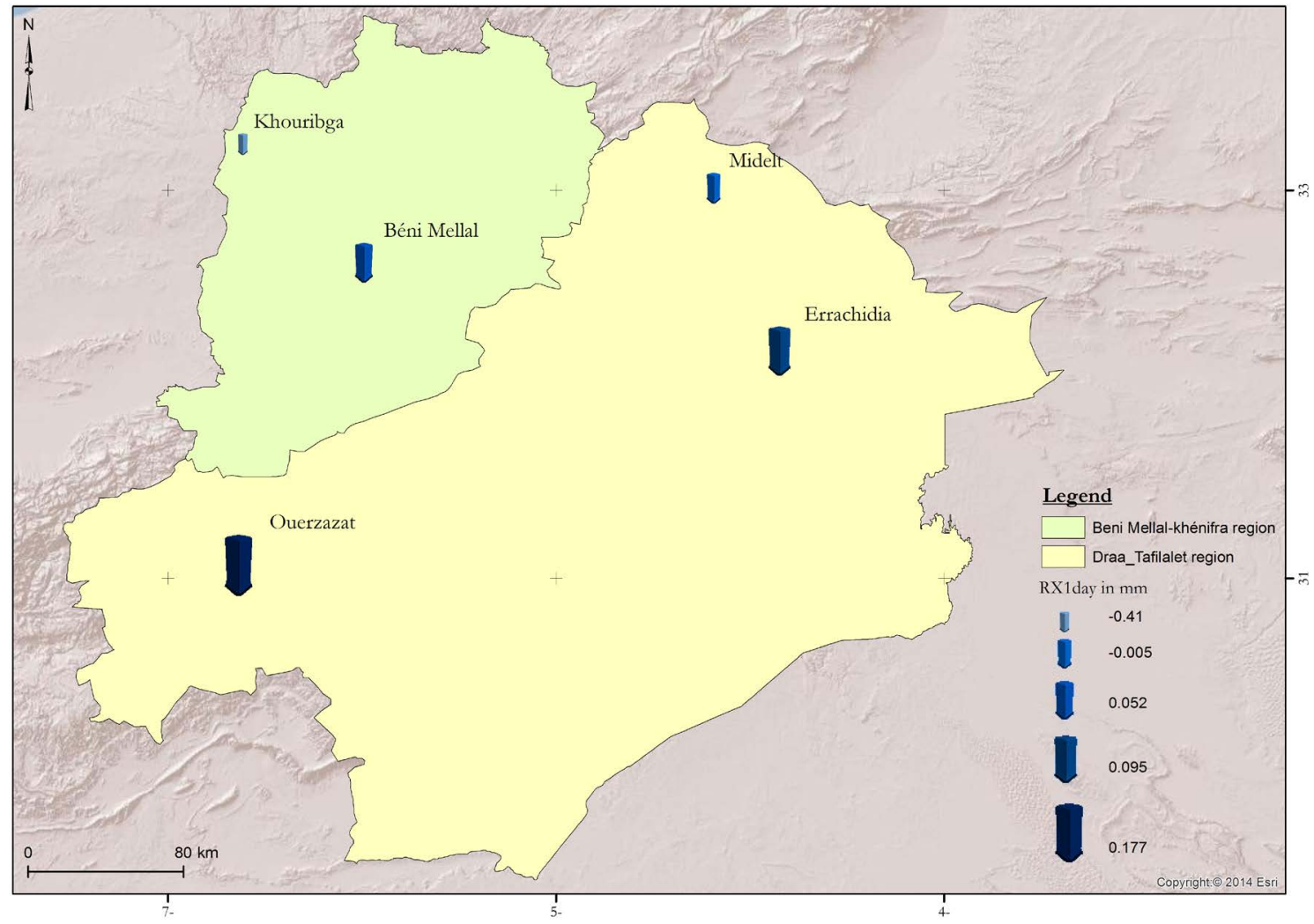

Figure 7. Maximum height of the precipitation in one day in different stations.

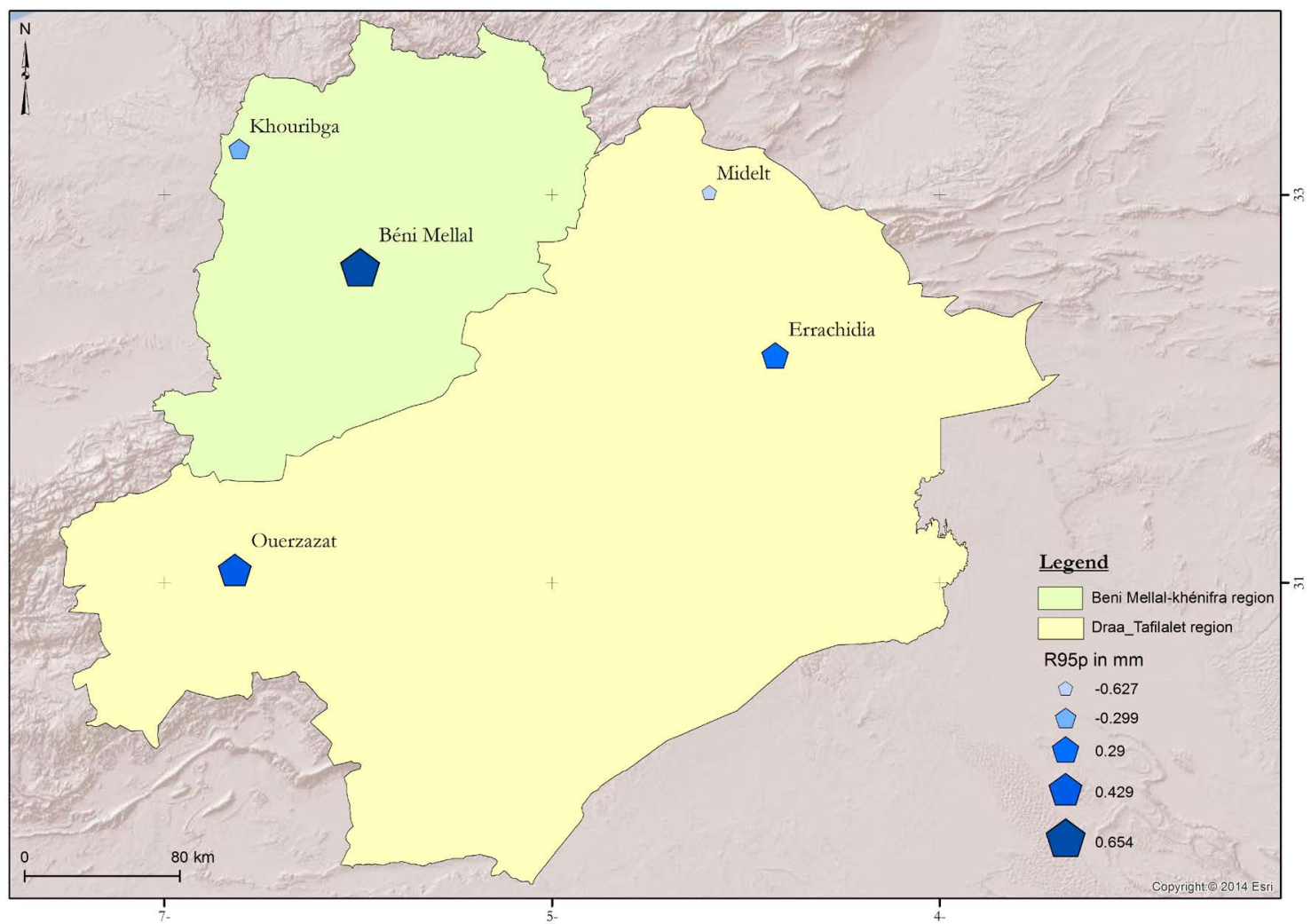

Figure 8. Very wet days index trends. 


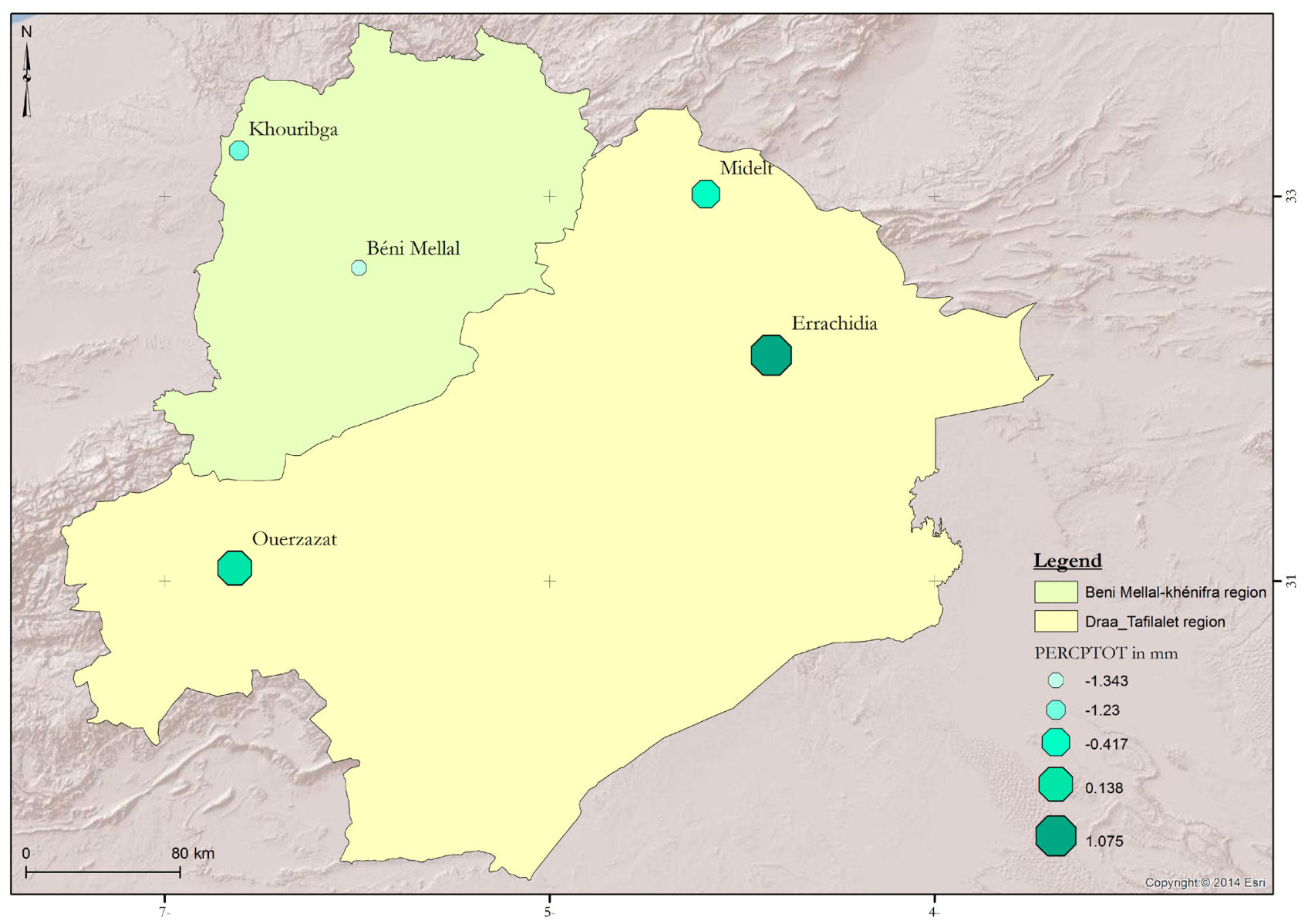

Figure 9. PRCPTOT index trends of total annual precipitations.

\section{4) Consecutively dry days (CDD)}

This index evolution is marked by a very considerable decline in Ouarzazate -0.647 days/year. In the other stations as Errachidia there is a rather low decline is that does not exceed -0.481 days/year. In Beni Mellal and Midelt station they are successively characterized by a rise of 2 days/decade and 3 days/decade. This increase is more pronounced in Khouribga, which has a trend of 7.65 days/decade of consecutive days without rain (Figure 10).

Synthesis: The two regions rainfall (Beni Mellal-Khenifra and Daraa-Tafilalt) is marked by a variable evolution. This recession is reflected in a downward trend in climate change indices for stations and an increase in other stations, particularly for rainfall totals, consecutive wet days and consecutive dry days. 


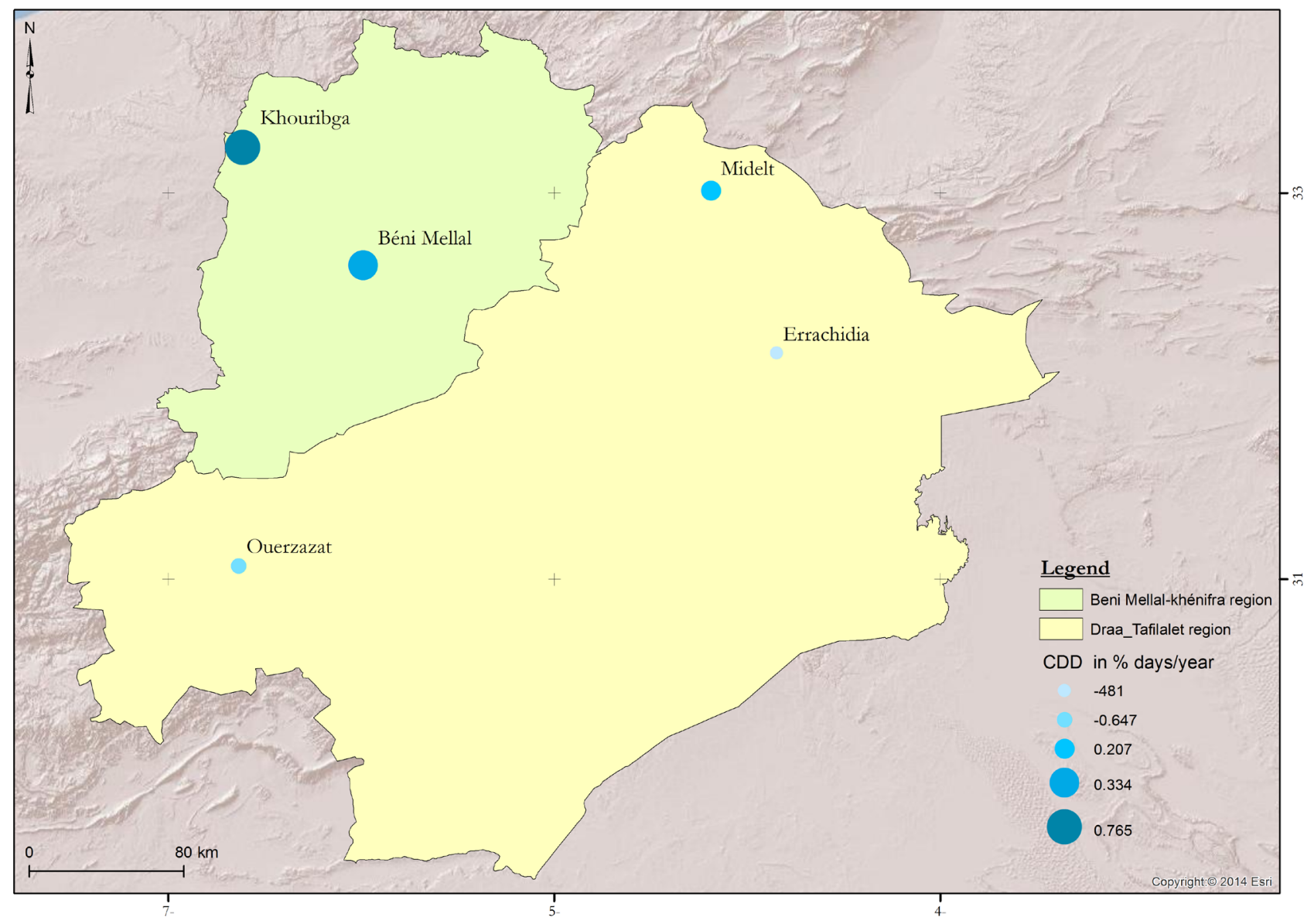

Figure 10. Spatial distribution of consecutive day index trends.

\section{Conclusions}

The objective of this work is to provide a summary of extreme and average climate trends observed in the Beni Mellal-Khenifra and Darâa-Tafilalt regions over the last four decades. The indices were calculated based on daily maximum and minimum observations for temperatures and precipitation. Trends were calculated for five weather stations from 1970 to 2016.

For temperature trends, a large number of stations are experiencing significant trends, which would confirm an increase in temperature in the study area and subsequently widening of the hot season and shrinking of the cold season. The results also show a decrease in the number of cold nights and an increase in the number of hot days and indicator of the durations of hot sequences. In addition, precipitation behavior is difficult to analyze given the geographic position and terrain that influences their random distributions.

Precipitation decreases especially in Khouribga and Midelt. This decrease is materialized by a decrease in annual rainfall totals, consecutive wet days, and maximums of a rainy day. An upward trend of consecutively dry days is observed in Beni Mellal, Khouribga and Midelt. Note that these trends are not statistically significant. 
In general, the different evolutions of the temperatures and precipitations did not induce a change of the type of climate in the studied regions.

\section{References}

[1] Bertrand, F. and Larrue, C. (2007) Gestion territoriale du changement climatique -Une analyse à partir des politiques régionales. Programme Gestion et Impacts du Changement Climatique-2. Université UMR CITERES.

[2] Maley, J. (1980) Les changements climatiques de la fin du Tertiaire en Afrique: Leur conséquence sur l'apparition du Sahara et de sa végétation. Sahara Nile, 63-86.

[3] The Intergovernmental Panel on Climate Change (IPCC). http://www.ipcc.ch

[4] Nicholls, N., Gruza, G.V., Jouzel, J., Karl, T.R., Ogallo, L.A. and Parker, D.E. (1996) Observed Climate Variability and Change. Cambridge University Press.

[5] Alexander, L.V., Zhang, X., Peterson, T.C., Caesar, J., Gleason, B., Klein Tank, A.M.G., Haylock, M., Collins, D., Trewin, B. and Rahimzadeh, F. (2006) Global Observed Changes in Daily Climate Extremes of Temperature and Precipitation. Journal of Geophysical Research: Atmospheres, 111. https://doi.org/10.1029/2005JD006290

[6] Frei, C. and Schär, C. (2001) Detection Probability of Trends in Rare Events: Theory and Application to Heavy Precipitation in the Alpine Region. Journal of Climate, $14,1568-1584$. https://doi.org/10.1175/1520-0442(2001)014<1568:DPOTIR >2.0.CO;2

[7] Groisman, P.Y., Knight, R.W., Easterling, D.R., Karl, T.R., Hegerl, G.C. and Razuvaev, V.N. (2005) Trends in Intense Precipitation in the Climate Record. Journal of Climate, 18, 1326-1350. https://doi.org/10.1175/JCLI3339.1

[8] Osborn, T.J. and Hulme, M. (2002) Evidence for Trends in Heavy Rainfall Events over the UK. Philosophical Transactions of the Royal Society A: Mathematical, Physical \& Engineering Sciences, 360, 1313-1325.

https://doi.org/10.1098/rsta.2002.1002

[9] Sen Roy, S. and Balling, R.C. (2004) Trends in Extreme Daily Precipitation Indices in India. International Journal of Climatology, 24, 457-466. https://doi.org/10.1002/joc.995

[10] Frich, P., Alexander, L.V., Della-Marta, P.M., Gleason, B., Haylock, M., Tank, A.K. and Peterson, T. (2002) Observed Coherent Changes in Climatic Extremes during the Second Half of the Twentieth Century. Climate Research, 19, 193-212. https://doi.org/10.3354/cr019193

[11] Kiktev, D., Sexton, D.M., Alexander, L. and Folland, C.K. (2003) Comparison of Modeled and Observed Trends in Indices of Daily Climate Extremes. Journal of Climate, 16, 3560-3571. https://doi.org/10.1175/1520-0442(2003)016<3560:COMAOT>2.0.CO;2

[12] Moberg, A., Sonechkin, D.M., Holmgren, K., Datsenko, N.M. and Karlén, W. (2005) Highly Variable Northern Hemisphere Temperatures Reconstructed from Low- and High-Resolution Proxy Data. Nature, 433, 613-617. https://doi.org/10.1038/nature03265

[13] Fauchereau, N., Trzaska, S., Rouault, M. and Richard, Y. (2003) Rainfall Variability and Changes in Southern Africa during the 20th Century in the Global Warming Context. Natural Hazards, 29, 139-154. https://doi.org/10.1023/A:1023630924100

[14] Hulme, M., Doherty, R., Ngara, T., New, M. and Lister, D. (2001) African Climate 
Change: 1900-2100. Climate Research, 17, 145-168.

https://doi.org/10.3354/cr017145

[15] Kruger, A.C. and Shongwe, S. (2004) Temperature Trends in South Africa: 1960-2003. International Journal of Climatology, 24, 1929-1945.

https://doi.org/10.1002/joc.1096

[16] Mahé, L.-P. and Ortalo-Magné, F. (2001) Politique agricole: Un modèle européen. Presses de sciences po.

[17] Malhi, Y. and Wright, J. (2004) Spatial Patterns and Recent Trends in the Climate of Tropical Rainforest Regions. Philosophical Transactions of the Royal Society of London, 359, 311-329. https://doi.org/10.1098/rstb.2003.1433

[18] Requier-Desjardins, M. (2010) Impacts des changements climatiques sur l'agriculture au Maroc et en Tunisie et priorités d'adaptation. Cent. Int. Hautes Études Agron. Méditerranéennes Montp.

[19] El Bihi, Y. (2017) Les politiques de gestion du risque et de la sécurité routière au Maroc, Territorialisation et problèmes de gouvernance. Cas de la région Béni Mellal Khénifra.

[20] Mohamed, B.A. (2014) Nouveaux aspects démographiques au regard du développement dans le pré-Sahara marocain: Cas du Darâa-Tafilalt. Rev. AFN Ma$\operatorname{roc} \mathrm{N} 12,14$.

[21] Zhang, X. and Yang, F. (2004) RClimDex (1.0) User Manual. Climate Research Branch Environment Canada Downs View, Ontario, 22.

[22] Sensoy, S., Türkoğlu, N., Akçakaya, A., Ekici, M., Demircan, M., Ulupinar, Y., Atay, H., Tüvan, A. and Demirbaş, H. (2013) Trends in Turkey Climate Indices from 1960 to 2010. 6th Atmospheric Science Symposium, Ankara, 24-26.

[23] Sohrabi, M.M., Marofi, S. and Ababaei, B. (2009) Investigation of Temperature and Precipitation Indices by Using RClimDex and R Software in Semnan Province. International Conference on Water Resources, 16-18.

[24] Zhang, X., Aguilar, E., Sensoy, S., Melkonyan, H., Tagiyeva, U., Ahmed, N., Kutaladze, N., Rahimzadeh, F., Taghipour, A. and Hantosh, T.H. (2005) Trends in Middle East Climate Extreme Indices from 1950 to 2003. Journal of Geophysical Research: Atmospheres, 110, D22104. 